\title{
A Mecsek kaparódarázs faunájának (Hymenoptera: Sphecoidea) faunisztikai, állatföldrajzi és ökofaunisztikai vizsgálata*
}

\author{
JÓZAN ZSOLT
}

\begin{abstract}
JóZAN Zs. Faunistical, zoogeographical and ecofaunistical investigation on the Sphecoids fauna of the Mecsek Mountains (Hymenoptera: Sphecoidea)

Abstract: The author publishes the list of the Sphecoids fauna of the Mecsek Mountains (SW Hungary) in this paper. He gives a characterisation of the fauna from faunistical, zoogeographical and ecofaunistical point of view. All data are summarised in the tables 1-7.

Mimumesa beaumonti (Lith.) Tachysphex figax (Rad.) and Tachysphex plicosus (Costa) are new species in the Hungarian Specoids fauna.
\end{abstract}

\section{Bevezetés}

A Mecsek Hymenoptera faunájának rendszeres kutatását az 1950-es évek elején Móczár László kezdte el. A gyüjtőmunkába bekapcsolódott Bajári E. és Móczár M. is. A szerző 1963-tól közel három évtizeden keresztül vizsgálta a hegység fullánkos Hymenoptera faunáját, melynek eredményeképpen jelentős anyagot sikerült összegyüjteni mind faj-, mind példányszám tekintetében. A gyüjtőmunkában számottevő segítséget nyújtott Józan Zsoltné. A Természettudományi Múzeum determinálatlan kaparódarázs anyagának feldolgozása során számos ritka faj mecseki példányait sikerült megtalálni, melyeket Móczár L. és Gebhardt A. gyüjtöttek. A Pécsi Janus Pannonius Múzeum munkatársai is hozzájárultak a rovaranyag gyarapításához.

A kaparódarazsakra vonatkozó faunisztikai adatoknak csak kisebb részét sikerült eddig publikálni, illetve feldolgozni (BAJÁRI 1956, 1957, JózAN 1985, MóczÁr 1958, 1959). Ezen publikációkban mindössze 22 faj mecseki lelőhelyét lehet megtalálni. DélDunántúl kaparódarázs faunájának alapvetésekor a Mecsekből már 82 faj előfordulását ismertük (JóZAN 1985).

Ebben a munkában a hegység faunájának elemzése elnagyolt volt. E cikk megjelenését követô öt évben jelentősen nőtt az ismert fajok száma, és a lelőhelyek is számottevően gyarapodtak. Lehetővé vált a hegyvidék faunájának részletesebb elemzése. Az eddig megjelent publikációk, valamint a szerző kiadás alatt lévő munkái lehetővé tették a vizsgált terület összehasonlítását más magyarországi tájakkal (Benedek 1979, JózAN 1986, 1989). Taxonómiai kérdésekben, valamint a fajok elterjedési jellegének megitélésében Balthasar (1972), Bohart és Menke (1976), és PUlawski (1971) munkáit használtam fel. A faunaelemzést MóczÁr (1948), BENEDEK (1979) és saját publikációim szempontjai szerint végzem. Az utóbbi évtizedben a Mecsek területén a gyüjtőmunka alkalomszerüvé vált, ennek eredményét e publikáció nem tartalmazza.

* A cikk a Magyar Rovartani Társaság 1991. évi pályázatán első dijat kapott. 


\section{Faunisztikai és állatföldrajzi értékelés}

A majdnem 40 éve folyó gyűjtőmunka eredményeképpen 144 Sphecoidea faj került elö a Mecsek területén. Ez a teljes hazai fauna $50 \%$ - a. Ennél többet Magyarország tájai közül csak a Bakonyban és a Kiskunsági Nemzeti Park területén mutattak ki (1. táblázat). A fajok alcsaládonkénti összetétele a vizsgált területünkön eltér a teljes hazai faunáétól. A Larrinae fajok részesedése magasabb, valamivel több a Crabroninae alcsalád részaránya is. Ezzel szemben a Mecsekben viszonylag kevés Nyssoninae és Astatinae faj került elő. Nincs számottevő eltérés a Sphecinae és a Pemphredoninae fajok esetében. A Philanthinae alcsaládnál teljes egyezés alakult ki (2. táblázat). A hegység déli és északi

\section{1. táblázat: A Mecsekben, Magyarországon és néhány más hazai területen előkerült kaparódarázs fajok száma alcsaládonként.}

\begin{tabular}{|l|c|c|c|c|c|c|c|c|c|}
\hline & $\begin{array}{c}\text { Magyar- } \\
\text { ország }\end{array}$ & Mecsek & $\begin{array}{c}\text { Mecsek } \\
\text { déli } \\
\text { oldal } \\
\text { oldal }\end{array}$ & $\begin{array}{c}\text { Mecsek } \\
\text { északi } \\
\text { Bakony }\end{array}$ & $\begin{array}{c}\text { Tihanyi } \\
\text { TK }\end{array}$ & $\begin{array}{c}\text { Zselic } \\
\text { Kiskunsági } \\
\text { NP }\end{array}$ & $\begin{array}{c}\text { Bükki } \\
\text { NP }\end{array}$ \\
\hline Ampulicinae & 2 & 2 & 1 & 2 & 1 & - & 1 & 1 & - \\
\hline Sphecinae & 19 & 10 & 10 & 5 & 9 & 7 & 7 & 14 & 3 \\
\hline Pemphredoninae & 47 & 23 & 20 & 13 & 34 & 16 & 20 & 23 & 13 \\
\hline Astatinae & 13 & 5 & 5 & 2 & 6 & 2 & 4 & 11 & 2 \\
\hline Larrinae & 37 & 22 & 21 & 9 & 19 & 9 & 19 & 25 & 4 \\
\hline Crabroninae & 84 & 44 & 34 & 33 & 51 & 30 & 37 & 46 & 18 \\
\hline Nyssoninae & 58 & 25 & 21 & 9 & 25 & 15 & 21 & 29 & 7 \\
\hline Philanthinae & 26 & 1 & 11 & 7 & 15 & 12 & 12 & 17 & 4 \\
\hline Entomosericinae & 2 & - & - & - & - & - & - & - & - \\
\hline Sphecoidea & 288 & 144 & 123 & 80 & 160 & 91 & 121 & 166 & 52 \\
\hline
\end{tabular}

\section{2. táblázat: A Mecsek, Magyarország és néhány más hazai terület kaparóda- rázs fajainak százalékos megoszlása alcsaládonként}

\begin{tabular}{|l|c|c|c|c|c|c|c|c|c|}
\hline & $\begin{array}{c}\text { Magyar- } \\
\text { ország }\end{array}$ & Mecsek & $\begin{array}{c}\text { Mecsek } \\
\text { déli } \\
\text { oldal }\end{array}$ & $\begin{array}{c}\text { Mecsek } \\
\text { északi } \\
\text { oldal }\end{array}$ & Bakony & $\begin{array}{c}\text { Tihanyi } \\
\text { TK }\end{array}$ & $\begin{array}{c}\text { Zselic } \\
\text { Kiskunsági } \\
\text { NP }\end{array}$ & $\begin{array}{c}\text { Bükki } \\
\text { NP }\end{array}$ \\
\hline Ampulicinae & 0,69 & 1,39 & 0,81 & 2,50 & 0,63 & - & 0,83 & 0,60 & 1,92 \\
\hline Sphecinae & 6,60 & 6,94 & 8,13 & 6,25 & 5,63 & 7,70 & 5,78 & 8,43 & 5,77 \\
\hline Pemphredoninae & 16,32 & 15,97 & 16,26 & 16,25 & 21,25 & 17,60 & 16,53 & 13,86 & 23,08 \\
\hline Astatinae & 4,51 & 3,47 & 4,07 & 2,50 & 3,75 & 2,20 & 3,31 & 6,63 & 3,85 \\
\hline Larrinae & 12,85 & 15,28 & 17,07 & 11,25 & 11,88 & 9,90 & 15,70 & 15,06 & 7,69 \\
\hline Crabroninae & 29,17 & 30,56 & 27,65 & 41,25 & 31,86 & 34,00 & 30,58 & 27,71 & 36,34 \\
\hline Nyssoninae & 20,14 & 17,36 & 17,07 & 11,25 & 15,63 & 16,50 & 17,35 & 17,47 & 13,46 \\
\hline Philanthinae & 9,03 & 9,03 & 8,94 & 8,75 & 9,37 & 12,10 & 9,92 & 10,24 & 7,69 \\
\hline Entomosericinae & 0,69 & - & - & - & - & - & - & - & - \\
\hline
\end{tabular}


oldalán előkerült fajok alcsaládonkénti megoszlásában jelentős különbségek vannak. Az északi oldal faunájában jóval jelentősebb a Crabroninae alcsalád részesedése, mint a déli lejtőkön élőében. A Philaanthinae és a Pemphredoninae fajok részaránya jó egyezést mutat a két területen. Az északi oldalon előkerült két Ampulicinae faj az összes faj 2,5\%a, míg a déli oldalon gyüjtött egy faj az ottani fajok $1 \%$-át sem éri el. A Sphecinae, Astatinae, Larrinae és Nyssoninae fajok részesedése a déli oldalon jelentősebbnek bizonyult, mint az északin.

A Mecsek faunájának alcsaládonkénti fajösszetétele a Zselicéhez áll a legközelebb. A két táj egymással határos, a faunaalakító hatások érvényesülése hasonló volt. A Dunántúl másik hegyvidékén, a Bakonyban jóval több Pemphredoninae és Crabroninae, ugyanakkor kevesebb Larrinae és Nyssoninae faj került elő. Ugyanezt tapasztaljuk, bár kisebb mértékű arányeltolódással, a Tihanyi TK-tel való összehasonlításban is. A Kiskunsági NP faunájával való összevetésben szembetünő, hogy itt a Sphecinae, Astatinae és a Philanthinae fajok részaránya magasabb, mint a Mecsekben. Érdekes, hogy a Larrinae és a Nyssoninae alcsalád részesedése jó egyezést mutat. A túlnyomórészt hideg-és nedvességkedvelő Pemphredoninae és Crabroninae fajok a Mecsekben jelentősebb számarányúak (2. táblázat).

A faunahasonlóságot alcsaládonként számítottuk ki a Jaccard-index alapján. E tekintetben a legnagyobb mértékü hasonlóság a Mecsek és a Bakony között alakult ki, annak ellenére, hogy a fajok alcsaládok szerinti megoszlásában a Zselic áll közelebb a vizsgált területhez. Ez utóbbi tájjal valamivel kevesebb a közös faj, a Jaccard-index értéke a teljes Sphecoidea faunára vonatkozóan 0,04-dal alacsonyabb, mint a Bakony és a Mecsek faunája között (3. táblázat). Az összehasonlított hét alcsalád közül négy esetében a Mecsek és a Bakony között, kettő esetében pedig a Mecsek és a Zselic között nagyobb a faunahasonlóság értéke. Az előzetes várakozással ellentétben a mecseki fauna kevésbé hasonlít a tihanyi, mint a kiskunsági faunához. A Bükki NP-kal való igen kismértékű hasonlóság jól mutatja, hogy a Mecsek Sphecoidea faunájának fajösszetétele igen messze áll a montán jellegü faunáétól.

\section{3. táblázat: Faunahasonlóság a Mecsek, valamint más magyarországi területek Sphecoidea faunái között a Jaccard-index szerint}

\begin{tabular}{|l|c|c|c|c|c|c|}
\hline \multicolumn{1}{|c|}{ alcsaládok } & Mecsek & Bakony & $\begin{array}{c}\text { Tihanyi } \\
\text { TK }\end{array}$ & Zselic & $\begin{array}{c}\text { Kiskunsági } \\
\text { NP }\end{array}$ & $\begin{array}{c}\text { Bükki } \\
\text { NP }\end{array}$ \\
\hline Sphecinae & & 0,58 & 0,56 & 0,42 & 0,5 & 0,3 \\
\hline Pemphredoninae & & 0,6 & 0,5 & 0,43 & 0,48 & 0,29 \\
\hline Astatinae & & 0,83 & 0,4 & 0,8 & 0,45 & 0,4 \\
\hline Larrinae & & 0,58 & 0,35 & 0,58 & 0,52 & 0,18 \\
\hline Crabroninae & & 0,7 & 0,45 & 0,69 & 0,53 & 0,24 \\
\hline Nyssoninae & & 0,52 & 0,33 & 0,53 & 0,4 & 0,19 \\
\hline Philanthinae & & 0,75 & 0,47 & 0,79 & 0,58 & 0,13 \\
\hline Sphecoidea & & 0,63 & 0,42 & 0,59 & 0,5 & 0,25 \\
\hline
\end{tabular}


A mecseki kaparódarázs fauna diverzitására jellemző, hogy a Magyarországon ismert 61 nemből a hegységben 44 előkerült. A nagyobb fajszámúak közül az Ammophila, Podalonia, Mimumesa, Diodontus, Pemphredon, Passaloecus, Tachysphex, Trypoxylon, Oxybelus, Lindenius, Crossocerus, Ectemnius és a Gorytes nemek fajszáma meghaladja a hazai fajok 50\%-át. A kisebb fajszámúak közül jelentősek az Ampulex, Dolichurus, Stigmus, Dinetus, Entomognathus, Lestica, Lestiphorus, Hoplisoides és a Philanthus nemek. Kevés faja került elő a Mimesa, Psenulus, Astata, Tachytes, Miscophus, Rhopalum és az Alysson nemeknek. Egyáltalán nem sikerült gyüjteni Palmodes, Prionyx, Psen, Spilomena, Ammoplanus, Solierella, Crabro és Didineis fajokat. Ez utóbbiak közül a környező tájakon már számos faj elökerült, így a Mecsekben is számíthatunk elöfordulásukra. Kicsi a valószínüsége a Dryudella, Belomicroides, Entomosericus, Stizus és Stizoides fajok előfordulásának (8. táblázat).

A Mecsek kaparódarázs faunáját vizsgálhatjuk a fajok elterjedési jellege szerint is. A széles elterjedésúek (holarktikus, palearktikus, nyugat-palearktikus és euroszibériai) részaránya kerekítve 42 százalék. Az összehasonlított területek sorában ez az érték közepes. A hegyvidékek közül a Bakonyban kevesebb, a Bükkben jóval több ezen fajcsoport részesedése. Érdekes, hogy a zselici faunában mintegy 2, a tihanyiéban pedig több, mint 8 százalékkal magasabb a széles elterjedésü fajok hányada, mint a vizsgált területen. A Kiskunsági Nemzeti Parkban a legalacsonyabb ezek részaránya. A Mecsek északi és déli oldalának faunája között e tekintetben 10 százaléknyi különbség alakult ki. Az európai elterjedésü állatok részaránya a Mecsekben magas, több, mint 24 százalék. Ennél több csak a Zselic kaparódarazsai között található. A hegység északi és déli oldala között ebben a tekintetben is kialakult a 10 százaléknyi eltérés. A Mecsekben a déli elterjedésű fajok (holo-, ponto- és északmediterrán) részaránya valamivel több 32 százaléknál. Ezzel az értékkel megelőzi a tihanyi és a zselici faunát. a Bakonyban ezen fajok részesedése jóval magasabb, holott ezt a tényt előzetes feltételezésünk nem valószínúsítette. E tény arra is felhívja a figyelmet, hogy az egyes tájak faunáinak fejlödésében a térbeli földrajzi fekvésnek hazánkban kisebb volt a szerepe, mint az ökofaunisztikai tényezőknek. A Kiskunsági Nemzeti Parkban a déli elterjedésü fajok számaránya 12 százalékkal magasabb, mint a Mecsekben. A 44 százaléknyi részarány még a hegység déli oldalán élő faunát is jóval meghaladja. A vizsgált tájunk két oldalának faunájában e tekintetben alakult ki a legjelentősebb különbség. Az északi területeken gyüjtött fajoknak csak 16 százaléka déli elterjedésủ állat, ez az érték igen közel áll a Bükki NP faunájához (7. táblázat).

\section{Ökofaunisztikai értékelés}

A Sphecoidea faunát jól jellemzi a fajok ökofaunisztikai jellege szerinti megoszlás is. A Mecsek kaparódarazsai közül 64,5 százalék meleg- és szárazságkedvelő (eremophil), és mintegy 29 százaléka hideg- és nedvességkedvelő (hylophil). A legszélesebb türéshatárú (hipereuryök) fajok részesedése alig több 8 százaléknál. Az eremophil fajok kereken 13 százaléka szüktürésű (stenoök). Ez az érték elég magas, hiszen az összehasonlított területek közül csak a Kiskunsági NP faunájában találunk magasabb részesedést ezen fajoknál. A Bakony és a Mecsek faunájában a stenoök eremophil számaránya lényegében megegyezik. Az eremophil fajok 49 százaléka tágtűrésű (euryök). A Mecsek faunája ezzel ez értékkel is az összehasonlitott tájak első csoportjába sorolható a Tihanyi TK-tel a Zseliccel és a Kiskunsági NP-kal együtt. A hylophil fajok részesedése inkább közepesnek mondható, különösen, ha a montán jellegü bükki és a főleg száraz homoki biotópokban élő kiskunsági fauna szélsőséges értékeit nem vesszük figyelembe. 


\section{4. táblázat: A Mecsek és más magyarországi területek Sphecoidea faunáinak százalékos megoszlása a fajok ökofaunisztikai jellege szerint}

\begin{tabular}{|c|c|c|c|c|c|c|c|c|}
\hline & 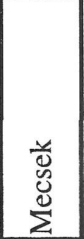 & 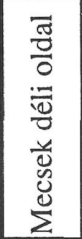 & 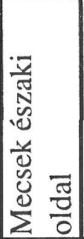 & 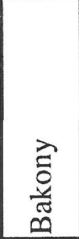 & 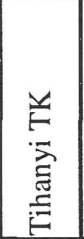 & 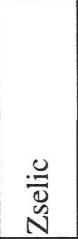 & 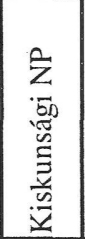 & 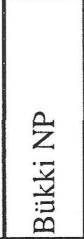 \\
\hline stenoök eremophil & 13,19 & 14,52 & 2,53 & 13,00 & 11,00 & 10,74 & 23,49 & - \\
\hline euryök eremophil & 49,31 & 54,84 & 41,77 & 45,50 & 49,90 & 48,76 & 51,81 & 30,19 \\
\hline hipereuryök intermedier & 8,33 & 8,87 & 12,66 & 7,50 & 12,10 & 9,92 & 6,63 & 13,21 \\
\hline euryök hylophil & 29,17 & 21,77 & 43,04 & 33,50 & 27,50 & 30,58 & 17,47 & 50,94 \\
\hline stenoök hylophil & - & - & - & 0,60 & - & - & 0,60 & 5,66 \\
\hline eremophil összesen & 62,50 & 69,36 & 44,30 & 58,50 & 60,40 & 59,50 & 75,30 & 30,19 \\
\hline hylophil összesen & 29,17 & 21,77 & 43,04 & 34,10 & 27,50 & 30,58 & 18,07 & 56,60 \\
\hline eremophil/hylophil arány & 2,14 & 3,19 & 1,03 & 1,71 & 2,20 & 1,95 & 4,17 & 0,53 \\
\hline
\end{tabular}

Stenoök hylophil faj a Mecsekben nem került elő (4. táblázat). A vizsgált terület északi és déli oldalán előkerült fajok megoszlása sajátos. A hegység főgerincétől északra eső lelőhelyeken előkerült darázsfajok igen kis hányada stenoök eremophil, ugyanekkor az euryök eremophil állatok részesedése kevésbé marad el a teljes faunáétól. A hylophil fajok részaránya kétszer akkora, mint a hegység déli oldalának faunájában. Érdekes, hogy a Mecsekkel északnyugaton közvetlenül határos Zselic faunájában a fajok megoszlása jelentősen eltér a hegység északi oldaláétól. A déli lejtőkön élő faunában az eremophil fajok hányada meglehetősen magas, de nem éri el a Kiskunsági NP faunájának hasonló értékét, mert a stenoök faunaelemek aránya lényegesen alacsonyabb.

Az egyes faunák jellegét igen jól fejezi ki az eremophil fajok hylophilokkal szembeni túlsúlya, melyet a hányadosukkal fejezhetünk ki. Ez a Mecsek esetében 2,14-nak adódott. Ez a hányadosérték csak a kiskunsági fauna esetében nagyobb ennél, majdnem kétszer akkora. A bakonyi faunában a hylophil fajok számaránya nagyobb, így a szóbanforgó hányados értéke csak 1,71. A Mecsek északi területei faunájának ezen hányadosértéke majdnem kétszerese a Bükki Nemzeti Parkénak. A déli lejtőkön élő faunában több, mint háromszor annyi eremophil faj él, mint hylophil (4. táblázat).

Az egyes tájak faunáját összehasonlíthatjuk a közös és a nem közös fajok ökofaunisztikai jellegének megoszlása szerint is. A Mecsek és a Bakony összevetésében szembetűnik, hogy a csak a Mecsekben gyüjtött fajoknál jóval magasabb az eremophilok részesedése. Ugyanez tapasztalható, ha a tihanyi és a zselici faunával hasonlítjuk össze a szóbanforgó tájat. A bükki fauna igen eltérő jellege ebben az összehasonlításban is kitünik. A csak itt kimutatott fajok háromnegyed része hylophil, ebből tekintélyes hányad stenoök hylophil. A csak a Mecsekben előkerült fajok közel háromnegyede viszont eremophil. A Kiskunsági NP kaparódarazsainak fajösszetétele szintén sajátos, hiszen a csak itt gyűjtött fajok közel fele, míg csak a Mecsekben előkerülteknek alig negyede stenoök eremophil. Az euryök eremophil fajok esetében is megmutatkozik ez az eltérés.

A hylophil fajok megoszlásában is tapasztalhatjuk ugyanezeket, de ellentétes módon. Az eremophil fajok túlsúlyát kifejező hányados értéke is jól mutatja az egyes területek faunájának jellegzetességét, kifejezve a hegyvidéki vagy síkvidéki arculatot, az egyes biotóptípusok egymáshoz képesti arányát, mikroklimatikus vonásait. A Mecsek az öszszehasonlított tájak között a xerotherm élőhelyek gazdagságával tünik ki. A fenti elemzés adatait az 5-6. táblázat foglalja össze. 
A Mecsek Sphecoidea faunájának kialakulásában döntő szerepe volt a klimatikus és domborzati tényezőknek, valamint a növénytakarónak. A hegység kőzettani felépítése változatos. A középső részeit és a Zengő tömbjét a jó hőháztartású, különböző korú mészkövek, a Nyugati-Mecseket homokkövek és konglomerátumok építik fel. A hegység déli lábainál homokfeltárások vannak, melyek közül Makárhegy, Pécsszabolcs, Hird és Pécsvárad környékén fekvőkben történtek gyüjtések. Az északi lejtőket sokfelé agyagos lejtőüledékek fedik, melyek darázsfaunája szegényesebb, mint a löszterületeké.

A magasabb térszint a mérsékelten nedves, enyhe telü hegyvidéki klímakörzethez tartozik. Ilyen mezoklíma a Bakonyban csak a közepes magasságú területeken van. A Mecsek alacsonyabb területei a mérsékelten nedves, enyhe telü dombsági klímakörzethez sorolhatók, ahol az óceáni hatások vannak túlsúlyban. A déli lejtőkön az utolsó tavaszi fagy átlagos határnapja április 10-e, az első őszi fagy átlagos határnapja október 25-e és 30-a közé esik. Ez tulajdonképpen a korai tavaszodásban és az enyhe hömérsékletü őszökben nyilvánul meg.

A déli lejtők természetes növénytakarójában a darázsfauna szempontjából nagy jelentőségüek a karsztbokorerdőt tagoló lejtősztyepp és sziklagyep foltok. Ilyen biotópokban sokat gyüjtöttünk a Tettye, a Dömörkapu, a Tubes és a Misina területén. Itt túlnyomórészt az eremophil Ammophila, Podalonia, Sphex, Liris, Astata, Philanthus, Cerceris, Nysson, Belomicrus fajokon kívül a főképp homoki biotópokban élö Bembix, Bembecinus, Tachysphex, Tachytes és Palarus fajok némelyike is előkerült. Ez utóbbiakat a déli hegylábi övezetben fekvő homokfeltárásokban is sokfelé megtaláltuk. A meleg-száraz biotópokban a leglátogatottabb növények az Eryngium campestre, a Falcaria vulgaris, az Achillea millefolium, a Dorycnium germanicum, az Allium sphaerocephalum, a Sedum acre és a Thymus fajok voltak. A Nyugati-Mecsek homokkövének és konglomerátumának mállott felszínén a lazább talajokon élö Tachysphex és Mischopus fajok is megtelepedtek.

A patakmenti magaskórós társulások és mocsárrétek, valamint a szegélytársulások ernyősvirágú növényein (Angelica silvestris, Heracleum sphondylium, Pastinaca sativa) túlnyomórészt az északi oldalon gyüjtöttünk. Itt került elő a Pemphredoninae és Crabroninae alcsalád legtöbb faja.

\section{5. táblázat: A Mecsek, a Bakony, a Tihanyi TK és a Zselic Sphecoidea faunájának százalékos megoszlása a közös és nem közös fajok ökofaunisztikai jellege szerint}

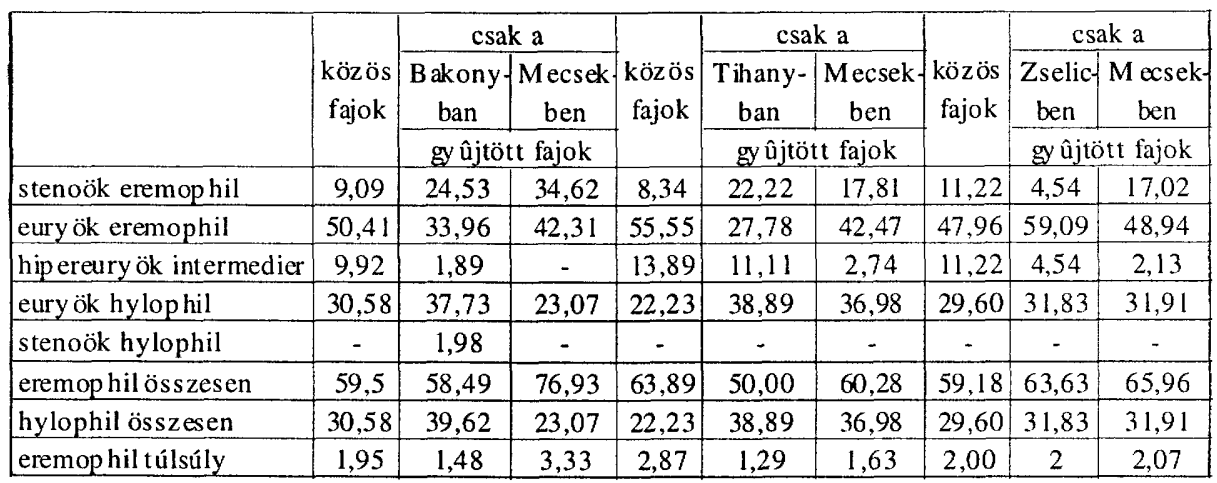


6. táblázat: A Mecsek, a Kiskunsági Nemzeti Park és a Bükki Nemzeti Park Sphecoidea faunájának százalékos megoszlása a közös és nem közös fajok ökofaunisztikai jellege alapján

\begin{tabular}{|c|c|c|c|c|c|c|}
\hline & \multirow{3}{*}{ közös fajok } & \multicolumn{2}{|l|}{ csak a } & \multirow{3}{*}{ közös fajok } & \multicolumn{2}{|c|}{ csak a } \\
\hline & & Kiskunsági NP-ban & Mecsekben & & Bükki NP-ban & Mecsekben \\
\hline & & gyüjtött faj & & & gyüjtött & fajok \\
\hline stenoök eremophil & 8,65 & \begin{tabular}{|l|}
46,78 \\
\end{tabular} & 24,39 & - & - & 18,27 \\
\hline euryök eremophil & 60,58 & 35,48 & 19,51 & 35,00 & 16,67 & 53,84 \\
\hline hipereuryök intermedier & 9,62 & 1,61 & 2,44 & 15,00 & 8,33 & 5,78 \\
\hline euryök hylophil & 21,15 & 14,52 & 53,66 & 50,00 & 50,00 & 22,11 \\
\hline stenoök hylophil & - & 1,61 & - & - & 25,00 & - \\
\hline eremophil összesen & 69,23 & 82,26 & 43,90 & 35,00 & 16,67 & 72,11 \\
\hline hylophil összesen & 21,25 & 16,13 & 53,66 & 50,00 & 75,00 & 22,11 \\
\hline eremophil túlsúly & 3,27 & 5,06 & 0,82 & 0,70 & 0,22 & 3,26 \\
\hline
\end{tabular}

\section{7. táblázat: A Mecsek és más magyarországi területek Sphecoidea faunáinak százalékos megoszlása a fajok elterjedési jellege szerint}

\begin{tabular}{|l|c|c|c|c|c|c|c|c|}
\hline & Mecsek & $\begin{array}{c}\text { Mecsek } \\
\text { déli } \\
\text { oldal }\end{array}$ & $\begin{array}{c}\text { Mecsek } \\
\text { északi } \\
\text { oldal }\end{array}$ & Bakony & $\begin{array}{c}\text { Tihanyi } \\
\text { TK }\end{array}$ & Zselic & $\begin{array}{c}\text { Kiskunsági } \\
\text { NP }\end{array}$ & $\begin{array}{c}\text { Bükki } \\
\text { NP }\end{array}$ \\
\hline holarktikus & 4,86 & 4,03 & 7,59 & 5,60 & 5,50 & 4,96 & 3,61 & 7,55 \\
\hline palearktikus & 32,65 & 33,87 & 37,97 & 29,40 & 41,70 & 33,88 & 28,31 & 45,28 \\
\hline nyugat-palearktikus & 4,17 & 4,03 & 5,06 & 4,40 & 6,60 & 4,69 & 4,22 & 5,66 \\
\hline euroszibériai & 0,69 & - & 1,27 & - & 1,10 & 0,83 & - & 3,77 \\
\hline európai & 19,44 & 18,55 & 27,85 & 20,00 & 13,20 & 21,48 & 13,26 & 22,64 \\
\hline atlantikus & 0,69 & - & 1,27 & - & - & - & 1,20 & - \\
\hline közép-európai & 4,17 & 3,23 & 2,53 & 1,90 & - & 4,13 & 4,22 & 1,89 \\
\hline észak- és közép-európai & - & - & - & 0,60 & - & - & - & - \\
\hline ponto-kaszpikus & 0,69 & 0,81 & - & - & - & - & - & - \\
\hline holomediterrán & 9,03 & 10,48 & 3,80 & 13,10 & 8,80 & 9,93 & 16,87 & 7,55 \\
\hline pontomediterrán & 15,97 & 17,74 & 6,33 & 16,30 & 16,50 & 13,22 & 18,07 & 3,77 \\
\hline északmediterrán & 7,64 & 7,26 & 6,33 & 8,70 & 3,30 & 6,61 & 9,64 & 1,89 \\
\hline
\end{tabular}

A települések területén igen jó gyüjtőhelyeknek bizonyultak a régi épületek kő- és vályogfalai, deszkaépítmények és faoszlopok. Ilyen helyeken találtuk az Ampulex, Nitela, Trypoxylon, Pison, Diodontus, Passaloecus és Stigmus fajok jó részét.

\section{Magyarország faunájára új fajok}

Mimumesa beaumonti (van Lith, 1949) - Abaliget, 1984. 07. 1-15., Malaise-csapda, 1 nőstény. - Igen ritka faj, melynek eddig Hollandiából, Belgiumból és Lengyelországból említik előfordulását (BALTHASAR 1972, BOHART és MENKE 1976). Az utóbbi néhány évben Magyarország négy pontjáról sikerült kimutatni. Abaligeten kivül előkerült Ujszentmargitán, Lakitelek: Tőserdőn, és Sárospatakon a Bodrog partján. A faunaterületen ezek az első lelőhelyei. 
Tachysphex fugax (Radoszkowski, 1877) - Pécs: Makárhegy, 1965. 07. 13. (leg. Józan), 1966. 06. 16. (leg. Józan), 2 hím; Pécsvárad: vár környéke, 1988. 07. 11. (leg. Józan), 1 nőstény. - A mediterrán területeken szélesen elterjedt állat. A Kanári-szigetektől az Arab-félszigeten és Kis-Ázsián át Turkesztánig sokfelé megtalálták. Dél-Afrikában is él. Magyarországhoz legközelebbi élőhelyei Jugoszláviában Nis, Olaszországban Velence környéke (PULAWSKI 1971). A Mecseken kívül még Kaposvár környékén is sikerült gyűjjteni. A faunaterületen ezideig még nem gyüjtötték.

Tachyspex plicosus (Costa, 1867) - Pécsvárad: vár környéke, 1988. 07. 11. (leg. Józan), 1 nőstény, 1 hím. - mediterrán faj, melyet Dél-Európában Franciaországtól Olaszországon át a Balkán több országáig kimutatták. Romániában Gugesti lelőhelye ismert. Afrikában Marokkó, Egyiptom és Szudán területén gyüjtötték. Előfordul Kis-Ázsiában és Azerbajdzsánban is. A faunaterületen csak Crikvencia környékén került elő (PULAWSKı 1971). A Természettudományi Múzeumban nincsenek példányai.

\section{A fauna jelentősebb színező elemei}

A Magyarországon igen ritka fajok közül a Chlorion magnificum Mor., a Belomicrus italicus Costa és a Cerceris stratiotes Schlett. előfordulását a hazai szakirodalom már közölte. Az alábbiakban néhány más, nagyon ritka faj lelöhelyeit közöljük.

Ammophila hungarica Mocsáry, 1883 (=fallax Kohl, 1884) - Pécs: Budai-vám, 1955. 07. 12. (leg. Móczár L.), 1 nőstény. - Igen ritka mediterrán faj. Nálunk csak Dunaörsröl, Simontornyáról és a Budai-hegyekből került elő (BAJÁRI 1957).

Diodontus insidiosus Spooner, 1938 - Hosszúhetény: Püspökszentlászló, 1990. 07. 23. (leg. Józan), 1 nőstény. - Az utóbbi évek kutatásai során e fajt kimutatták Kiskunsági NP-ban Bugacpusztáról (JóZAN 1986). Legelőször a Brit-szigeteken és Svájcban gyüjtötték (BOHART és MENKE 1976).

Tachysphex grandii Beaumont, 1956 - Hird, 1980. 07. 21. (leg. Józan), 1 nőstény; Pécs. Makárhegy, 1966. 07. 20., Tettye, 1972. 06. 19., Zsebe-domb, 1975. 07. 08. (leg. Józan), 2 nőstény, 2 hím. - Stenoök eremophil, pontomediterrán faj. Magyarországon simontornyai lelőhelyét irodalmi adatként ismertük (PULAWSKI 1971). Az utóbbi évtizedben elökerült a Bakony több pontján, a Barcsi borókásban, a Zselicben (JóZAN 1989) és Bugacpusztán is (KARSAI 1988).

Nysson roubali Zavadil, 1937 - Pécsvárad: Haraszt, 1989. 06. 17. (leg. Józan), 1 hím. - Igen ritka, közép-európai állat, melyet ezideig csak Dél-Szlovákiában és Simontornyán találtak.

Lestiphorus bicinctus (Rossi, 1794) - Abaliget, 1984. 06. 16-30., Malaise-csapda, 1 hím. - Euryök hylophil, palearktikus elterjedésű faj. Magyarországon eddig csupán öt, hegy- és dombvidéki lelőhelyről ismertük (BAJÁrı 1957, BENEDEK 1979).

Lestiphorus bilunulatus Costa, 1869 - Pécs: Szuadó-völgy, 1957. 08. 13. (leg. Gebhardt), 2 hím - Föleg Közép-Európából ismert ritka állat. Nálunk elöször a Zselicből és Igal környékéről közölték előfordulását (JózAN 1985). 


\section{8. táblázat : A gyújtött fajok jegyzéke \\ $(A=$ a lelöhelyek száma a déli oldalon, $B=$ a lelőhelyek száma az északi oldalon, + =a Mecsek faunájára új, ++ = Magyarország faunájára új)}

\author{
Ampulicinae \\ Ampulex fasciata Jur.+ \\ Dolichurus corniculus (Spin.)
}

\section{Sphecinae}

Chlorion magnificum Mor. Sceliphron destillatorium (I1l.)

Sphex rufocinctus Br.

Ammophila campestris Latr.

Ammophila heydeni Dhlb.

Ammophila hungarica Mocs.+ Ammophila sabulosa (L.)

Podalonia affinis (K.)

Podalonia tydei Guill.

Podalonia hirsuta (Scop.)

\section{Pemphredoninae}

Mimesa equestris (Fabr.)

Mimumesa atratina (Mor.)

Mimumesa beaumonti (Lith.) ++ Mimumesa dahlbomi (Wesm.)+ Mimumesa unicolor (Lind.)

Psenulus fiscipennis (Dhlb.)

Psenulus pallipes (Pz.)

Diodontus insidiosus Spooner+ Diodontus luperus Shuck.

Diodontus major Kohl

Diodontus minutus (Fabr.)

Diodontus tristis (Lind.)

Pemphredon inornatus Say

Pemphredon lethifer (Shuck.)

Pemphredon lugurbis (Fabr.)

Pemphredon lugens Dhlb.+

Pemphredon rugifer Dhlb.

Passaloecus corniger Shuck.

Passaloecus gracilis Curt.

Passaloecus insignis (Lind.)+

Passaloecus singularis Dhlb.

Stigmus pendulus $\mathrm{Pz}$.

Stignus solskyi Mor.

\section{Astatinae \\ Astata boops (Schrk.) \\ Astata gallica Bcaum. \\ Astata minor Kohl \\ Dinetus pictus (Fabr.)}

\section{Larrinae}

Liris nigra (Fabr.)

Tachytes europaeus $\mathrm{Kohl}$

Tachysphex bicolor $\mathrm{Br}$.

Tachysphex fugax (Rad.)++

Tachysphex fulvitarsis (Costa)

Tachysphex grandii Beaum.+
A B

Tachysphex helveticus Koh1

Tachysphex incertus (Rad.)

21 Tachysphex nitidus (Spin.)

Tachysphex plicosus (Costa)++

Tachysphex pompiliformis (Spin.) $\quad 7 \quad 2$

Tachysphex psammobius (Kohl) $\quad 4 \quad 2$

21 Palarus variegatus (Fabr.) 5

Miscophus bicolor Jur.

3 Miscophus spurius (Dhlb.)

4 Nitela spinolae Latr.+

Pison atrum (Spin.)

5 Trypoxylon attenuatum Sm.

Trypoxylon clavicerum Lep. et Scrv.

Trypoxylon figulus (L.)

3 Trypoxylon fronticorne Guss.

Trypoxylon scutatum Chevr.+

\section{Crabroninae}

Belomicrus italicus Costa

Oxybelus bipunctatus Oliv.

Oxybelus lineatus (F.)

Oxybelus mucronatus (F.)

Oxybeltus quattordecimnotatus Jur. $\quad 5 \quad 1$

$\begin{array}{lll}\text { Oxybelus trispinosus (F.) } & 2 & 2\end{array}$

Oxybelus uniglumis (L.)

Oxybelus variegatus Wesm.

Oxybelus victor Lep.

1 Entomognathus brevis (Lind.)

4 Entomognathus dentifer (Nosk.)

Lindenius albilabris (F.)

2 Lindenius laevis Costa

2 Lindenius panzeri (Lind.) +

$1 \quad$ Lindenius pygmaeus armatus (Lind.)

Rhopalum clavipes (L.)+

Crossocerus assimilis (Sm.)+

Crossocerus binotatus Lep. et Br.

Crossocerus capitosus (Shuck.)

1 Crossocerus cetratus (Shuck.)+

Crossocerus distinguendus (Mor.)

2 Crossocerus elongatulus (Lind.)+

Crossocerus exiguus (Lind.)+

Crossocerus megacephalus (Rossi)+

1 Crossocerus ovalis Lep. ct Br.t

Crossocerus podagricus (Lind.)

2 Crossocerus quadrimaculatus (F.)

Crossocerus vagabundus (Pz.)

Crossocerus wesmaeli (Lind.) +

Ectemnius cavifrons (Ths.)

Ectemnius cephalotes (Oliv.)

Ectemnius confinis (Walker)+

Ectemnius continuus (F.)

Ectemnius crassicornis (Spin.)

1 Ectemnius dives (Lep. et $\mathrm{Br}$.)

Ectemnius fossorius (L.) +
B 


\section{8. táblázat : folytatás}

Ectemnius lapidarius (Pz.)

Ectemnizs lituratus (Pz.)

Ectemnius meridionalis (Costa)

Ectemnius rubicola (Duf. ct Pcrr.)

Ectemnius ruficornis (Zctt.)+

Ectemnius rugifer (Dhlb.)+

Lestica alata $(\mathrm{Pz}$.)

Lestica clypeata (Schreb.)

\section{Nyssoninae}

Mellinus arvensis (L.)

Alysson spinosus (Pz.)

Nysson dimidiatus Jur.

Nysson roubali Zav.t

Nysson spinosus (Forst.)

Nysson trimaculatus (Rossi)+

Nysson variabilis Chevr.

Argogorytes mystaceus (L.)

Dienoplus affinis (Spin.) +

Dienoplus elegans (Lep.)+

Dienoplus laevis (Latr.)

A $\quad$ B

3 Gorytes quinquecinctus (F.)

A B

$1 \quad 10$

Gorytes quinquefasciatus $(\mathrm{Pz}$.)

42

11 Lestiphorus bicinctus (Rossi)+

23 Lestiphorus bilumulatus Costa+

1 Hoplisoides latifrons (Spin.) +

2

1

1

4

Dienoplus moravicus (Snof1.)

Gorytes fallax Handl.+

Gorytes laticinctus (Lep.)

Gorytes procrustes Handl.

Gorytes quadrifasciatus (F.)

Hoplisoides punctuosus (Ev.)

Bembecinus tridens (Fabr.)

$4 \quad$ Bembix oculata $\mathrm{Pz}$.

Bembix rostrata (L.)

Bembix tarsata Latr.

1 Philanthinae

$4 \quad$ Philanthus coronatus (Thunb.) 3

$1 \quad$ Philanthus triangulum (F.) 6

1 Cerceris albofasciata (Rossi) 5

2 Cerceris arenaria (L.) $\quad 5 \quad 1$

$1 \quad$ Cerceris flavilabris (F.)

1 Cerceris hortivaga $\mathrm{Kohl}+$

$\begin{array}{lll}4 & 1 & \text { Cerceris interrupta }(\mathrm{Pz})+\end{array}$

$1 \quad$ Cerceris quadricincta (Pz.) 2

3 Cerceris quinquefasciata $(\mathrm{Pz})$

2 Cerceris rubida (Jur.)

11 Cerceris ruficornis (F.)

$\begin{array}{lll}1 & 1 & \text { Cerceris ruficornis }(\mathrm{F} .) \\ 1 & 3 & \text { Cerceris sabulosa }(\mathrm{Pz} .)\end{array}$

1 Cerceris stratiotes Schlctt. 


\section{Irodalom}

BAJÁRI, E. 1956: A csomósdarazsak (Cerceris Latr.) faunakatalógusa (Cat. Hym., VIII.). - Folia ent. hung. 9 (3): $79-88$.

BAJÁRI, E. 1957: Kaparódarázs alkatúak I. - Sphecoidea I. - Fauna Hung. XIII (7): 1-117.

BALTHASAR, V. 1972: Fauna CSSR. Grabwespen - Sphecoidea. - Verlag der Tschehosl. Akad. der Wissensch., Praha: 1.471 .

BENEDEK, P. 1979: A Bakony-hegysćg kaparódarázs (Hym., Sphecoidea) faunájának állatföldrajzi vizsgálata. - Veszprém m. Múz. Közl. 14: 221-237.

BOHART, M. and MENKE, S. 1976: Sphecid Wasps of the world: a generic revision: - University of California Press, Berkeley, Los Angeles, London: 1-695.

JóZAN, Zs. 1985: Dél-Dunántúl kaparódarázs (Hymenoptera, Sphecoidea) faunájának alapvetése. - A Janus Pann. Múz. Évk. 29 (1984): 53-86.

JóZAN, Zs. 1986: The Scolioid and Sphecoid wasps fauna of the Kiskunság National Park. -- in: Mahunka S. (Ed.): Fauna of the Kiskunság National Park, I., Akadémiai Kiad., Budapest: 365-381.

JóZAN, Zs. 1989: A Tihanyi Tájvédelmi Körzet fullánkos faunája (Hymenoptera, Aculcata), I. -- Folia Mus. Hist. Nat. Bakonyiensis, 8: 79-110.

KARSAI, 1. 1988: Ecofaunistical investigation of Sphecoid fauna on a sandy grassland. - Acta Biol. Szeged. 33: 97-106.

MÓCZÁR, L. 1948: Die Sechöhe und die ökologischen Gesichtspunkte in der Bezeichnung zoogeographischer Gebietseinheiten. - Fragm. Faun. Hung. 11: 85-89.

MóczÁr, L. 1958: A Crabroninac (Fam.: Sphecidac) alcsalád faunakatalógusa (Cat. Hym. XIII.) Fauncnkatalog der Subfamilic Crabroninae (Hym.) (Cat. Hym. Xlll.). - Folia cnt. hung. 11 (8): 189-216.

MócZÁR, L. 1959: Kaparódarázs alkatúak II. - Sphecoidea II. - Fauna Hung. XIII (8).: 1-87.

PULAWSKI, W. 1971: Les Tachysphex Kohl (Hym., Sphecidac) de la region palcarctique occidentalc et centrale. - Panst. Wydaw. Nauk., Wroclaw: 1-464. 


\section{Faunistical, zoogeographical and ecofaunistical investigation on the Sphecoids fauna of the Mecsek Mountains (Hymenoptera: Sphecoidea)}

\section{ZSOLT JÓZAN}

For forty years the author has recorded Specoids species in the Mecsek Mountains (SW Hungary); so now 144 species are known in this area.

The results show that 50 percentage of the Hungarian Specoids live in the Mecsek Mountains. The larger part of the collected material of Specoids belongs to Carrinae and Crabroninae subfamily. The numbers of Nyssoninae and Pemphredominae species seem to be fewer than the number of the whole Hungarian fauna (Table 2.)

Mimumesa beaumonti (Lith.), Tachysphex fugax (Rad.) and Tachysphex plicosus (Costa) are new species in the Hungarian Specoids fauna.

Chlorion magnificum occurs only in the Mecsek Mountains and the rarest species are Ampulex fasciata Jur., Diodontus insidiosus Spooner, Passaloecus insidiosus Spooner, Tachysphex grandii Beaum., Belomicrus italicus Costa, Crossocerus exiguus (Lind.), Nysson roubali Zav., Lestiphorus bicinctus (Rossi), Lestiphorus bilunulatus Costa, Cerceris stratiotes Schlett. The Sphecoid fauna of the Mecsek Mountains is similar to the fauna of the Bakony Mountains and the Zselic Hills (Table 3.) The proportion of the widespread species is 42 percentage, but the number of species having European distribution is rather high and the number of Mediterranean species seems to be high as well.

Ecofaunistical evaluation shows that the proportion of the eremophil species are 64.5 percentage, hylophil 29 percentage. Table 4 . shows that proportion of eremophil species is different. Considerable differences can be found in the faunistical elements between the southern and northern part of the Mecsek Mountains.

In the end the author compares the Specoids fauna of the Mecsek Mountains to that of some other Hungarian regions in the tables 1-7.

Author's address:

Zsolt JózAN

H-7453 Mernye

Rákóczi út 5.

HUNGARY 